\title{
Application of the Integration Model in the System of Inclusive Education
}

\author{
Marina Järvis ${ }^{1,2}$, Liudmyla Ivanenko ${ }^{3}$, Iryna Antonenko, ${ }^{4,}$, Tetiana Semenenko ${ }^{5}$, Anu Virovere ${ }^{1} \&$ Tetyana \\ Barantsova $^{6}$ \\ ${ }^{1}$ Estonian Entrepreneurship University of Applied Sciences, Tallinn, Estonia \\ ${ }^{2}$ Department of Business Administration, Tallinn University of Technology, Tallinn, Estonia \\ ${ }^{3}$ Department of Pedagogy, Correctional Education and Management, Chernihiv Regional Institute of Postgraduate \\ Pedagogical Education named after K.D.Ushynskyi, Chernihiv, Ukraine \\ ${ }^{4}$ Special Education and Psychology Department, Municipal Institution of Higher Education "Khortytsia National \\ Educational Rehabilitation Academy” of Zaporizhzhia Regional Council \\ ${ }^{5}$ Department of International Accounting and Audit, Kyiv National Economic University, Kyiv, Ukraine \\ ${ }^{6}$ Department of Education Management and Law, State Higher Educational Institution "University of Educational \\ Management" of the National Academy of Educational Sciences of Ukraine, Kyiv, Ukraine \\ *Correspondence: Special Education and Psychology Department, Municipal Institution of Higher Education \\ "Khortytsia National Educational Rehabilitation Academy" of Zaporizhzhia Regional Council, 59 Naukove \\ Mistechko Street (Khortytsia Island), 69017, Zaporizhzhia, Ukraine. E-mail: info@khnnra.zp.ua
}

Received: December 2, 2021

Accepted: January 4, 2022 Online Published: January 17, 2022

doi: $10.5430 /$ jct.v $11 \mathrm{n} 1 \mathrm{p} 35$

URL: https://doi.org/10.5430/jct.v11n1p35

\begin{abstract}
The introduction of inclusive education is an important factor in the development of society. The teacher plays special role in this context, the motivational readiness of teachers to work in an inclusive environment is important. The analysis of educational programmes showed that graduates of pedagogical majors are subject to equally high requirements for their psychological readiness to work with children with special educational needs. However, the educational components aimed at the formation of psychological readiness for the studied quality are not fully represented. Therefore, the aim of the study was to experimentally compare the motivational and value aspects of the psychological readiness of future teachers majoring in Special Education and Educational, Pedagogical Sciences to work in an inclusive educational environment. The research involved the method of T.I. Ilyina "Study of Educational Motivation in High School", the Inclusive Education Questionnaire, V.V. Boyko's Communicative Tolerance Test were used. Statistical analysis of the data was performed using the Mann-Whitney U-test, Fisher's $\varphi$-test. As a result it was determined that students majoring in Special Education have a higher level of psychological readiness to work in an inclusive educational environment than students majoring in Educational, Pedagogical Sciences. To sum up, it is necessary to strengthen educational programmes for teacher training with the components of inclusive education, as well as to include inclusive-oriented topics in the general professional subjects. We consider the study of cognitive and activity aspects of psychological readiness of future teachers to work in the inclusive education as a prospect for further research.
\end{abstract}

Keywords: motivation, values, future teachers, psychological readiness, inclusive education, inclusive educational environment, children with special educational needs

\section{Introduction}

Modern research states the fact that various developmental and behavioural disorders in children are increasingly common because of the influence of numerous factors, such as biogenic, sociogenic and psychogenic. In the traditional Ukrainian education system, children with special needs were educated in special (correctional) educational institutions, at home or in special boarding schools (Poroshenko, 2019). 
In recent decades, there has been a significant change in society's attitude towards people with health problems and assessing the capabilities of children with special educational needs. Since 2009, the country has been implementing legislative changes that ensured the education of children with special educational needs in inclusive groups and classes, the number of which is growing rapidly every year (State Service for Education Quality of Ukraine, 2021).

Today the society increasingly understands that child's psychophysical disorders do not deny the human nature, the ability to feel, gain social experience. In this regard, inclusion as a form of education is becoming more widespread. Inclusive education is a complex process that requires a certain transformation of the usual organization of the educational environment, certain socio-educational conditions that allow significant implementation of different approaches and methods to attract people with special educational needs in the educational space (Goodin, 1996).

However, despite many years of experience in inclusive policy in Ukraine, inclusive practices are not properly implemented in our country (Martynchuk et al., 2021). The problems of implementing inclusive education in our country and in other countries are associated with many challenges. In particular, it is the lack of architectural accessibility of most school buildings, inadequate professional training of teachers, their lack of experience in communicating with children with various diseases, insufficient readiness of society to adequately perceive the idea of integration (Hrabovets, Kalashnikova \& Chernous, 2020).

These and other problems have been reflected in Myronova et al. (2021). One of the main problems of inclusive education is insufficient training of teachers and lack of specialists, in particular, practical psychologists, future teachers of music (Ovcharenko et al., 2021), physical education (Catellani et al., 2018), defectologists (Martynchuk et al., 2021), teachers of secondary education in all areas (Ke, Borakova \& Valiullina, 2017).

Studies by Mngo and Mngo (2018) led to the conclusion that teachers with some training for teaching pupils with disabilities, as well as more experienced and highly educated teachers were more supportive of inclusive education, pointing out that resistance to this practice is due to insufficient preparedness or complete unpreparedness. Younger, less experienced teachers without special education indicated less enthusiasm for the benefits of inclusion, their ability to manage integrated classes, and to teach students with disabilities.

Lavrykova et al. (2020) note that the desire of future teachers to work in an inclusive educational environment is a stable personality trait, which is an important prerequisite for the education of children with disabilities, and is characterized by a focus on the implementation of the principles of inclusion in professional activities. Pit-ten et al. (2018) note that teachers often feel unprepared and, therefore, may fear the inclusion of students with special educational needs in regular classes.

Osero's (2015) study based on empirical data found that teachers faced such problems as lack of knowledge of student types, cases of indiscipline, time-consuming workload, teachers' negative attitudes towards students with disabilities, lack of conditions for teachers and students. The study found that the problems were due to teachers' negative attitudes towards inclusive education, and therefore hindered the implementation of inclusive education. Mpu and Adu (2021) obtained similar results, which notes that overcrowding, lack of training, lack of knowledge and skills of teachers were the main problems that led teachers to feel incompetent while teaching in a class with inclusive education. So, the value attitude towards children with special educational and needs and their motivation to work in such an environment is the basis of effective inclusive education.

The problem of motivational unpreparedness of teachers to work in an inclusive environment is raised in many countries. In India, Bhat and Geelani (2007) emphasize the lack of a positive attitude of teachers towards students with special educational needs. A study by Australian researchers Leif, Alfrey and Grove (2021) found that teachers do not feel properly prepared for inclusive education because they do not have sufficient opportunities to acquire the necessary knowledge, skills and strategies. In Estonia, Leijen, Arcidiacono and Baucal (2021) focus on the analysis of two opposing discourses on inclusive education, namely "inclusion for some" and "inclusion for all".

In Ukraine this issue is observed from different perspectives by Bessarab et al. (2021), Kichuk (2019), Prokopenko et al. (2020), Tserklevych et al. (2021), Zhuravlova et al. (2021) etc.

Teacher support is a key strategy for integrating students with special needs into regular classes (Leifler, 2020). Thus, the task of professional education in making bachelors of pedagogical majors ready for teaching in an inclusive environment is the cultivation of motivation, interest in working with children with special educational needs. It is important to cultivate the desire for further continuous self-education in this area, making students acquire a set of quality characteristics of future teachers of inclusive education (Bondar, Gumenyuk et al, 2021; Bondar, Humeniuk et al., 2021). It is necessary to emphasize the development of self-regulation, self-discipline, self-analysis, as 
Iatsyshyn et al. (2019) insist. We agree with Van Rensburg and Adcock (2020) that there is a need to raise awareness of the value of inclusive education among all stakeholders in this process.

So, the outlined problems determine the need to study the problem of developing motivational and value aspects of psychological readiness of future teachers to work in an inclusive environment. Given the above, the aim of this research is to study whether there are differences in the motivational and value characteristics of the psychological readiness of future teachers majoring in Special Education and Educational, Pedagogical Sciences to work in an inclusive educational environment.

The main objectives that follow from the research topicality and need to be fulfilled:

1. Identify the main problems of psychological readiness of future teachers to work in an inclusive educational environment.

2. Investigate whether there are differences in the psychological readiness of future teachers majoring in Special Education and Educational, Pedagogical Sciences to work in an inclusive educational environment.

3. Determine whether the educational components realize the motivational and value aspects of the psychological readiness of future teachers majoring in Educational, Pedagogical Sciences.

\section{Methods and Materials}

Comparative analysis of the development of motivational and value aspects of psychological readiness for teaching in an inclusive educational environment of students of two groups was carried out using a psychodiagnostic set of methods. Methods of Ilyina (2010) "Study of Educational Motivation in High School" allowed to determine what motives prevail in students during their studies at a higher educational institution (HEI). The Inclusive Education Questionnaire (Smolyar \& Chernomyrdina, 2019) allowed to determine the motivational and value attitude to the concept of "inclusive education". Boyko's (2002) Communicative Tolerance Test was used to study communicative tolerance, which is a characteristic of an individual's attitude to people, shows the degree of acceptance of unpleasant or unacceptable mental states, qualities and actions of interaction partners.

The research involved the method of, the Inclusive Education Questionnaire, Boyko's (2002) Communicative Tolerance Test were used. Statistical analysis of the data was performed using the Mann-Whitney U-test, Fisher's $\varphi$-test.

The following methods of mathematical and statistical analysis were used to process the results: Mann-Whitney U-test to identify differences in the studied feature in different groups of subjects, Fisher's $\varphi$-test to assess the reliability of differences between percentages. Statistical data processing was performed using SPSS 10 for Windows, Excel.

The analysis of educational programmes of experimental bases of universities allowed determining that the inclusive competence of students majoring in Educational, Pedagogical Sciences is formed during the study of individual educational components, including such subjects as Inclusive Education, Organization of Inclusive Education. Students majoring in Special Education learn a range of subjects, including Special and Inclusive Pedagogy, Anatomy, Physiology and Pathology of Children with the Basics of Genetics, Fundamentals of Neuropathology and Pathophysiology, Methods of Educational Work with Children with Special Educational Needs and others. The analysis also allowed determining that the psychological readiness of graduates of both majors to work with children with special educational needs should be at the same high level. These provisions were the starting point for the sampling.

The study involved Estonian Universities: Estonian Entrepreneurship University of Applied Sciences (Tallinn, Estonia); Department of Business Administration, Tallinn University of Technology (Tallinn, Estonia); Estonian Entrepreneurship University of Applied Sciences (Tallinn, Estonia). The experimental research was conducted on the basis of Ukrainian HEIs, namely Chernihiv Regional Institute of Postgraduate Pedagogical Education named after K.D. Ushynskyi (Chernihiv, Ukraine); Municipal Institution of Higher Education "Khortytsia National Educational Rehabilitation Academy" of Zaporizhzhia Regional Council (Zaporizhzhia, Ukraine); Kyiv National Economic University (Kyiv, Ukraine); State Higher Educational Institution "University of Educational Management" of the National Academy of Educational Sciences of Ukraine (Kyiv, Ukraine). Students of these universities made up a general population of 598 students majoring in Educational, Pedagogical Sciences and Special Education. After calculating the size of the required (representative) sample using an online calculator (with parameters: confidence probability - 85\%, error - 7\%), the size of a valid sample was 90 people (41 students majoring in Special Education and 49 students majoring in Educational, 
Pedagogical Sciences). Students studied in the $4^{\text {th }}$ year of the bachelor's level of higher education, which allowed determining the level of psychological readiness of future teachers to work in an inclusive educational environment.

The study was organized in three stages during 2020-2021. The empirical study was conducted in stages. The first stage was preparatory. This stage involved the choice, justification and theoretical understanding of the problem and research topic, the analysis of educational programmes, as well as studying the experience of previous research on the selected problem; the development of the programme, the technique of carrying out the experiment. The second (main) stage included a survey of students of both majors. The survey was conducted on a voluntary basis upon consent to process personal data. The third (final) stage involved processing of measurement data using software packages; interpretation of statistical indicators, comparison of the obtained results with the expected ones, and studies of previous researches on the chosen problem; presentation of research results.

\section{Results}

We describe the results of the study and present the data obtained.

Analysis of the results of the study obtained using the method of Ilyina (2010), which allows identifying not only the leading motives, but also the satisfaction of students with the choice of profession, convinces that the educational and professional activities of students are polymotivated. At the same time, students of both groups are dominated by motives for acquiring knowledge and mastering the profession (which indicates an adequate choice of profession and satisfaction with it). However, there were $5.18 \%$ more people with a predominance of such motives in the group of students majoring in Special Education, than in the group of students majoring in Educational, Pedagogical Sciences (Table 1).

The average value of motives on each scale was determined for a more thorough analysis of the data (Table 2). The table shows that the average value on the scale "Acquisition of knowledge" in the group of students majoring in Special Education is 0.5 higher than the average value in the group of students majoring in Educational, Pedagogical Sciences. The average value on the scale "Obtaining a diploma" in the two groups does not differ and is equal to 6.4. On the scale "Acquisition of knowledge", the average value in the group of students majoring in Special Education is higher than the average value in the other group by 1.4 .

Table 1. The Results of Studying the Motives of Learning in a Higher Educational Institution According to the Ilyina's Method

\begin{tabular}{lcc}
\hline \multicolumn{1}{c}{ Group } & $\begin{array}{c}\text { Number of students with a predominance } \\
\text { of motives for acquiring knowledge and } \\
\text { mastering the profession (in \%) }\end{array}$ & $\begin{array}{c}\text { Number of students with a } \\
\text { predominance of other types of } \\
\text { motives (in \%) }\end{array}$ \\
\hline Special Education & 31.71 & 88.29 \\
Educational, Pedagogical Sciences & 26.53 & 73.47 \\
\hline
\end{tabular}

Source: Ilyina (2010).

Table 2. Mean Scores on Scales in Different Groups of Subjects (Ilyina's method)

\begin{tabular}{lccc}
\hline \multirow{2}{*}{ Group } & \multicolumn{2}{c}{ Scale } \\
\cline { 2 - 4 } & Acquisition of knowledge & Mastering the profession & Obtaining a diploma \\
\hline Special Education & 7.9 & 6.2 & 6.4 \\
Educational, Pedagogical Sciences & 7.4 & 4.8 & 6.4 \\
\hline
\end{tabular}

Source: Ilyina (2010).

Data processing using the Mann-Whitney test showed statistically significant differences in indicators on the scale "Mastering the profession" (Table 3). The indicators of values on the scale "Mastering the profession" in students majoring in Special Education were higher. They allow us to state that the focus on mastering the profession in students of this group is higher than in students majoring in Educational, Pedagogical Sciences. 
Table 3. The Results of Comparing Indicators of Motives for Learning in a Higher Educational Institution on the Scales in Comparable Groups (Mann-Whitney U-test)

\begin{tabular}{|c|c|c|c|}
\hline Scale & $\begin{array}{l}\text { Empirical value of the } \\
\text { Mann-Whitney U-test }\end{array}$ & $\begin{array}{l}\text { Critical value of the } \\
\text { Mann-Whitney U-test }\end{array}$ & Getting into the significance area \\
\hline Acquisition of knowledge & 918.5 & $\mathrm{p} \leq$ & $\begin{array}{l}\text { The obtained empirical value is in the } \\
\text { insignificance area }\end{array}$ \\
\hline Mastering the profession & 681 & 0.01 & $\begin{array}{l}\text { The obtained empirical value is in the } \\
\text { significance area }\end{array}$ \\
\hline Obtaining a diploma & 999.5 & 716 & $\begin{array}{c}\text { The obtained empirical value is in the } \\
\text { insignificance area }\end{array}$ \\
\hline
\end{tabular}

The Inclusive Education Questionnaire was used to study the motivation of professional activity of future teachers in the inclusive environment and the need to acquire knowledge, skills and abilities necessary for teaching under such conditions, as well as attitudes to inclusive education and to children with special educational needs (Smolyar \& Chernomyrdina, 2019). The questions of one of the scales of the questionnaire are aimed at studying the attitude of students to future professional activity in the inclusive educational environment and preparation for it. The desire to work in an inclusive environment, the need to acquire knowledge, skills and abilities for such activities, awareness of the need for special training for future activities in such conditions are studied on another scale. The analysis of the answers to the questions of the questionnaire revealed the following results.

The readiness of students majoring in Special Education to work in inclusive educational environment is higher than in the other group:

a) the number of students majoring in Special Education with high and medium levels of motivation for professional activity in inclusive education and the need to obtain the necessary knowledge, skills was $48.78 \%$ and $39.03 \%$, while it was $18.36 \%$ and $40.82 \%$ for the group of students majoring in Educational, Pedagogical Sciences.

b) the number of students majoring in Special Education with high and medium levels of the value attitude towards the phenomenon of "inclusive education" was $46.34 \%$ and $51.22 \%$, and the number of students majoring in Education, Pedagogical Sciences was $30.61 \%$ and $30.61 \%$. The results of respondents' answers to the Inclusive Education Questionnaire are given in Table. 4.

Table 4. The Results of the Survey of Respondents Using the Inclusive Education Questionnaire (\%)

\begin{tabular}{|c|c|c|c|c|c|c|}
\hline \multirow[t]{2}{*}{ Readiness indicator } & \multicolumn{3}{|c|}{ Special Education } & \multicolumn{3}{|c|}{ Educational, Pedagogical Sciences } \\
\hline & Low level & Medium level & High level & Low level & Medium level & High level \\
\hline $\begin{array}{l}\text { Motivation of professional activi } \\
\text { inclusive educational environme } \\
\text { the need to obtain the necessary } \\
\text { knowledge, skills and abilities }\end{array}$ & 12.19 & 39.03 & 48.78 & 40.82 & 40.82 & 18.36 \\
\hline $\begin{array}{l}\text { Value attitude to the concept of } \\
\text { "inclusive education" }\end{array}$ & 2.44 & 51.22 & 46.34 & 38.78 & 30.61 & 30.61 \\
\hline
\end{tabular}

To assess the level of the studied readiness "Understanding and acceptance of another person's individuality", analysing the results of the study obtained using the Boyko's (2002) test, we identified three levels: high, medium, low. The number of students majoring in Special Education with a high level of the studied indicator is greater than the number of students majoring in Educational, Pedagogical Sciences with the same level by $22.99 \%$. It is important to note that there are no students majoring in Special Education with a low level at all. The results obtained are presented in Table 5 . 
Table 5. Levels of the Indicator "Understanding and Acceptance of the Individuality of Another Person" in Students of the Experimental and Control Groups (in \%)

\begin{tabular}{lccc}
\hline \multicolumn{1}{c}{ Group } & \multicolumn{3}{c}{ Level } \\
\cline { 2 - 4 } & Low & Medium & High \\
\hline Special Education & - & 34.15 & 65.85 \\
Educational, Pedagogical Sciences & 6.12 & 51.02 & 42.86 \\
\hline
\end{tabular}

Comparing the average values in both groups for tolerance, we found a difference of 1.8. Data processing using the Mann-Whitney test showed statistically significant differences in the indicators of understanding and acceptance of another person's individuality in students majoring in Education, Pedagogical Sciences and Special Education (Table $6)$.

Using the method of mathematical statistics, namely Fisher's $\varphi$-criterion, we revealed a statistically significant difference between the percentage of students majoring in Education, Pedagogical Sciences and Special Education with low and other levels of the indicators of motivational and value aspects of readiness (Table 7). Empirical data presented in Table 7 allow us to state that the percentage of students majoring in Special Education with high and medium levels of the studied indicators of the level of motivational and value aspects of psychological readiness for teaching in the inclusive educational environment is greater than the percentage of students majoring in Educational, Pedagogical sciences with the same level.

Table 6. The Results of Comparing the Data of the Indicator "Understanding and Acceptance of Another Person's Individuality" in Students of Comparable Groups (Mann-Whitney U-test)

\begin{tabular}{ccc}
\hline $\begin{array}{c}\text { Empirical value of the Mann-Whitney } \\
\text { U-test }\end{array}$ & $\begin{array}{c}\text { Critical value of the Mann-Whitney } \\
\text { U-test }\end{array}$ & Getting into the significance area \\
\hline 535 & $\mathrm{p} \leq 0.01 \mathrm{p} \leq 0.05$ & The obtained empirical value is in the \\
significance area
\end{tabular}

Table 7. The Results of Comparing the Percentages of Low, Medium, High Levels of Indicators of Motivational and Value Aspects of Psychological Readiness for Teaching in the Inclusive Educational Environment (Fisher's $\varphi$-test)

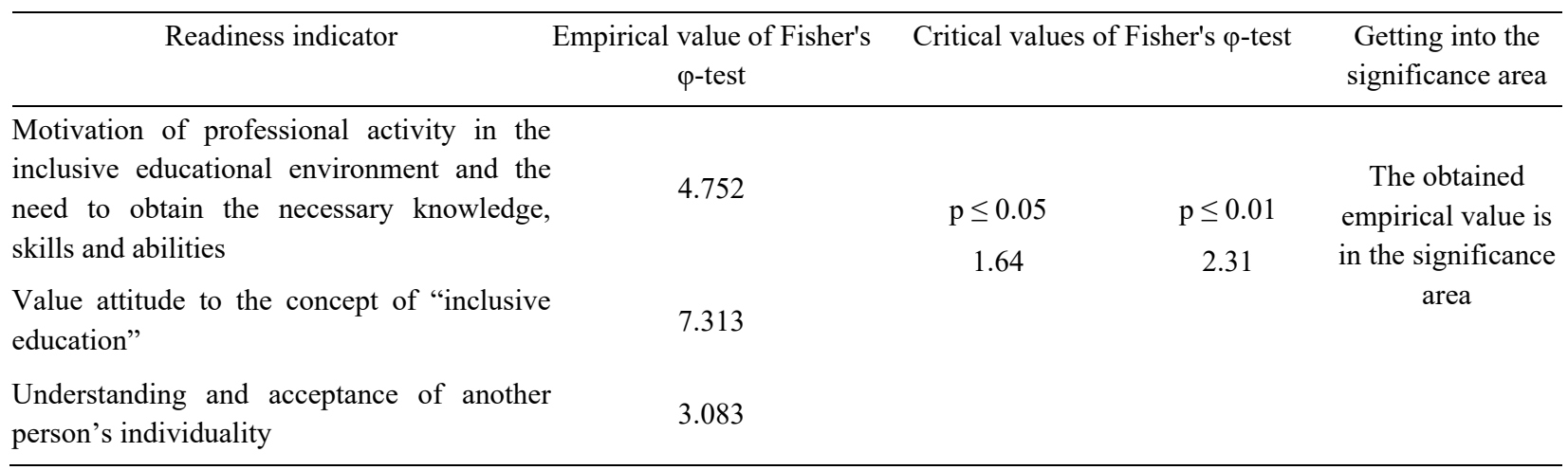

So, the identified differences allow us to talk about a higher level of motivational and value aspects of psychological readiness for teaching in an inclusive educational environment in students majoring in Special Education.

\section{Discussion}

As a result of experimental work, it was determined that students majoring in Special Education have a higher level of motivational and value psychological readiness of future teachers to work in an inclusive educational environment in all respects. The obtained results allow us to state that students of pedagogical majors without special training during professional education are not motivationally ready and do not have formed value orientations to work in the future in the inclusive educational environment. 
The results obtained through the method of studying the motives of learning in a higher education institution by Ilyina (2010) found differences in performance on the scale "Mastering the profession" allow us to conclude that students majoring in Special Education are purposeful to work with children with special needs, they consider this as their vocation. Students majoring in Educational, Pedagogical Sciences do not have established motives to work in the specialty, that is even in the pedagogical field. Ivanova et al. (2017) also revealed a decreased motivation of future teachers to master the profession by the end of their studies, which is a negative fact.

The answers of students to the Inclusive Education Questionnaire of students majoring in Special Education indicate:

- the positive attitude of future teachers to the joint education of children with different health status;

- knowledge and acceptance of such advantages of inclusive education as equal rights to education, formation of tolerance in all participants of the educational process (most often the answers indicated the formation of tolerance in healthy children in relation to children with special educational needs);

- $\quad$ the opportunity for children with special educational needs to adapt in society;

- understanding the need for special training for teaching in an inclusive educational environment (it was explained by the fact that "the process of education, upbringing, development of children with special educational needs requires a competent approach", "children with special educational needs have their own features that should be taken into account").

Analysis of the study by Yashchuk et al., (2020) confirms our findings that teacher training in Special Education is specifically focused on teaching children with special needs, and therefore their level of motivation is high. The authors explain this by the fact that their training includes special courses: neuropathology, basics of genetics, correctional pedagogy, etc., in contrast to educational programmes of other pedagogical majors.

Tarabanovskaya, Romanovskaya and Treshchov (2020) also confirmed the impact of inclusive-oriented courses on the level of inclusive competence of future teachers, although special training of teachers to work in inclusive education remains a problem of professional education in general (Magauova \& Makhambetova, 2019) and in training special education teachers in particular (Hergott, 2020).

The results obtained through the use of the Boyko's (2002) Communicative Tolerance Test allow us to state that students majoring in Special Education are ready to be tolerant when interacting with children with special educational needs. Our results correlate with Kunikowski, Pichkur and Stratan-Artyshkova (2017) on the point that future teachers with an ideal state of psychological readiness for inclusive education can potentially show high adaptability of behaviour, normal reactivity to stressful situations, determination to overcome difficulties. Attitudes towards people with disabilities play an important role in working in an inclusive environment (Lüke \& Grosche, 2018)

When analysing the answers of students majoring in Education, Pedagogical Sciences, it was determined that there were a large number of answers which demonstrated ignorance of the specifics of inclusive education; unwillingness to work in such conditions; confidence in the impossibility of development of children with special educational needs; the belief that only children with special educational needs have an advantage in inclusive education. The results of Hastings and Oakford (2003) also show a negative attitude of future teachers to work in an inclusive environment, in particular, teachers are more negative towards children with emotional and behavioural problems than towards children with intellectual disabilities.

\section{Conclusions}

The development of humanistic society dictates the need to train teachers for teaching in an inclusive educational environment. The problem of socialization and education of children with special educational needs is acute in Ukraine and other countries. Due to the peculiarities of development, these children require an individual approach and attention of educators. Solving this problem in full is not possible in the individual education, because these children need socialization and further integration into society along with the development of intelligence and acquiring knowledge. Therefore, the problem of equal access to educational resources by all children is currently addressed in the context of inclusive education. This determines the need to train appropriate teachers who are, above all, motivationally ready to work in an inclusive environment. Improving the system of this training requires finding existing problems and ways to solve them.

In the context of the above, we determined that the criterion characteristics of motivational and value aspects of psychological readiness for teaching in an inclusive educational environment are the motives of learning in higher 
educational institution, the desire to succeed in teaching in an inclusive educational environment, understanding and acceptance of the other people's individuality.

The results of the empirical study convince that students majoring in Special Education are not only focused on mastering the profession, but also understand the need for special training for professional activities in an inclusive educational environment. They not only have a positive attitude to the joint education of children with different health status to the phenomenon of "inclusive education", but also to the opportunities it provides for children with special educational needs and all its participants: equal rights to education, the formation of a tolerant attitude towards people in all participants in the educational process, the possibility of social adaptation for children with special educational needs, etc.

The comparative analysis of the data which resulted from the study of motivational and value aspects of psychological readiness of students of two groups for teaching in an inclusive educational environment convinces of the need for special work in the course of training of students majoring in Pedagogy and Education. Most students majoring in Educational, Pedagogical Sciences tend to misjudge the specifics of inclusive education, expresses reluctance to work in such conditions, the belief that the positive impact of such education affects only children with special educational needs, does not believe in the development of children with special educational needs. The results indicate that it is necessary to strengthen teacher training programmes with educational components of inclusion, as well as to include the development of inclusive-oriented topics in the general subjects.

The research materials can be used by teachers to create diagnostic programmes and monitor the motivational and value aspects of the psychological readiness of future teachers to work in an inclusive environment. The obtained results will be useful in the system of professional development and retraining of teachers, as well as guarantors of educational programmes for local monitoring.

We consider the study of cognitive and activity aspects of psychological readiness of future teachers to work in an inclusive educational environment as a prospect for further research.

\section{References}

Bessarab, A., Sadivnychyi, V., Ilchenko, A., Ripka, G., Shaposhnikova, V., \& Tainel, E. (2021). Development of students' research activity during studying at higher education institutions. Estudios de Economia Aplicada, 39(5). https://doi.org/10.25115/eea.v39i5.4866

Bhat, M. U. D., \& Geelani, S. Z. A. (2017). Inclusive education in India: issues, challenges, and prospects. The Communications, 25(1), 138-142.

Bondar, I., Gumenyuk, T., Horban, Y., Karakoz, O., \& Chaikovska, O. (2021). Distance E-learning in the system of professional development of corporation managers: Challenges of COVID-19. Journal of Education and e-Learning Research, 7(4), 456-463. https://doi.org/10.20448/journal.509.2020.74.456.463

Bondar, I., Humeniuk, T., Batchenko, L., Horban, Y., \& Honchar, L. (2021). State regulation of the development of educational and scientific process in higher education institutions. Journal of Management Information and Decision Sciences, 24(2), 1-10.

Boyko, V. V. (2002). Questionnaire "Diagnostics of empathic abilities". Retrieved from http://www.miu.by/kaf_new/mpp/013.pdf

Catellani, N., Ilyasov, D. F., Cherepov, E. A., Sevryukova, A. A., Selivanova, E. A., Kudinov, V. V., \& Nikolov, N. O. (2018). Development of psychological readiness in physical education teachers for the implementation of inclusive education. Human. Sport. Medicine, 18(1), 125-137. https://doi.org/10.14529/hsm180111

Goodin, R. E. (1996). Inclusion and exclusion. European Journal of Sociology/Archives Européennes de Sociologie, 37(2), 343-371. https://doi.org/10.1017/S0003975600007219

Hastings, R. P., \& Oakford, S. (2003). Student teachers' attitudes towards the inclusion of children with special needs. Educational psychology, 23(1), 87-94. https://doi.org/10.1080/01443410303223

Hergott, J. (2020). Effects of special education and feeling of inclusion (Master's thesis, Northwestern College, Orange City, IA). Retrieved from https://nwcommons.nwciowa.edu/education_masters/204/

Hrabovets, I., Kalashnikova, L., \& Chernous, L. (2020). The problems of implementation of inclusive education in Ukraine: generalization the experience of empirical sociological researches experience. SHS Web of Conferences, 75, 03011. https://doi.org/10.1051/shsconf/20207503011 
Iatsyshyn, A. V., Kovach, V. O., Romanenko, Y. O., \& Iatsyshyn, A. V. (2019). Cloud services application ways for preparation of future PhD. In: A. E. Kiv, \& V. N. Soloviev (Ed.), CEUR workshop proceedings (pp. 197-216) Kryvyi Rih, Ukraine: Kryvyi Rih State Pedagogical University.

Ilyina, T. I. (2010). Methodology for studying the motivation of learning at the university. Retrieved from https://psiukrearth.ru/psihologichni-testi-ta-igri/7849-metodika-vivchennja-motivacii-navchannja-u-vuzi-t.html

Ivanova, N. V., Minaeva, E. V., Lapin, N. I., Suvorova, O. V., \& Mamonova, Y. B. (2017). Specifics of the dynamics of educational activity motivation and antimotivation in students of a pedagogical university. Revista ESPACIOS, 38(40), 20.

Ke, Z., Borakova, N. U., \& Valiullina, G. V. (2017). Peculiarities of psychological competence formation of university teachers in inclusive educational environment. EURASIA Journal of Mathematics, Science and Technology Education, 13(8), 4701-4713. https://doi.org/10.12973/eurasia.2017.00947a

Kichuk, A. (2019). The health of the modern student: to the question of the mental and psychological components. Georgian Medical News, 291, 85-89.

Kunikowski, S., Pichkur, M., \& Stratan-Artyshkova, T. (2017). Future teachers' psychological readiness for inclusive teaching: coping-strategies. Science and Education, 12, 66-70. https://doi.org/10.24195/2414-4665-2017-12-9

Lavrykova, O., Kuzmenko, N., Demchenko, I., Kovalchuk, O., Slipchuk, V., \& Pilevych, O. (2020). Model of formation of future teachers' readiness to work in inclusive education. International Journal of Scientific \& Technology Research, 9(02), 410-414.

Leif, E., Alfrey, L., \& Grove, C. (2021). Challenges for delivering inclusive education in Australia. Retrieved from https://www.teachermagazine.com/au_en/articles/challenges-for-delivering-inclusive-education-in-australia

Leifler, E. (2020). Teachers' capacity to create inclusive learning environments. International Journal for Lesson and Learning Studies, 9(3), 221-244. https://doi.org/10.1108/IJLLS-01-2020-0003

Leijen, Ä., Arcidiacono, F., \& Baucal, A. (2021). The dilemma of inclusive education: inclusion for some or inclusion for all. Frontiers in Psychology, 12, 633066. https://doi.org/10.3389/fpsyg.2021.633066

Lüke, T., \& Grosche, M. (2018). What do I think about inclusive education? It depends on who is asking. Experimental evidence for a social desirability bias in attitudes towards inclusion. International Journal of Inclusive Education, 22, 38-53. https://doi.org/10.1080/13603116.2017.1348548

Magauova, A., \& Makhambetova, Z. (2019). Inclusive education abroad: problems, experience and perspectives. Kaznu Bulletin. Pedagogical Series, 58(1), 91-100. https://doi.org/10.26577/JES.2019.v58.i1.010

Martynchuk, O. V, Skrypnyk, T. V., Maksymchuk, M. O., Babych, N. M., \& Biryukova, K. D. (2021). Professional readiness of future special education teachers for inclusive education in Ukraine. In V. Lubkina, G. Strods, \& O. Vindaca (Eds.), Society. Integration. Education. Proceedings of the International Scientific Conference (Vol. 3, pp. 159-172). Rezekne, Latvia: Rēzeknes Tehnoloǵiju akadēmija. https://doi.org/10.17770/sie2021vol3.6409

Mngo, Z. Y., \& Mngo, A. Y. (2018). Teachers' perceptions of inclusion in a pilot inclusive education program: Implications for instructional leadership. Education Research International, 2018, 3524879. https://doi.org/10.1155/2018/3524879

Mpu, Y., \& Adu, E. O. (2021). The challenges of inclusive education and its implementation in schools: The South African perspective. Perspectives in Education, 39(2), 225-238. https://doi.org/10.18820/2519593X/pie.v39.i2.16

Myronova, S., Dokuchyna, T., Rudzevych, I., Smotrova, O., \& Platash, L. (2021). Current problems of teachers' readiness of higher educational institutions for implementing inclusive education. Revista Romaneasca Pentru Educatie Multidimensionala, 13(3), 151-165. https://doi.org/10.18662/rrem/13.3/445

Osero, P. O. (2015). Challenges teachers encounter in implementing inclusive education in public primary schools in Nyamira County, Kenya. Retrieved from http://kerd.ku.ac.ke/handle/123456789/730

Ovcharenko, N., Sysoieva, S., Samoilenko, A., Chebotarenko, O., \& Bohianu, K. (2021). Formation of prospective music art teachers' readiness for inclusive educational activity. Amazonia Investiga, 10(45), 175-184. https://doi.org/10.34069/AI/2021.45.09.18 
Pit-ten, C., Ineke, M., Markova, M., Krischler, M., \& Krolak-Schwerdt, S. (2018). Promoting inclusive education: the role of teachers' competence and attitudes. Insights into Learning Disabilities, 15(1), 49-63.

Poroshenko, M. A. (2019). Inclusive education: A textbook. Kyiv, Ukraine: LLC "Agency" Ukraine ".

Prokopenko, O., Osadchenko, I., Braslavska, O., Malyshevska, I., Pichkur, M., \& Tyshchenko, V. (2020). Competence approach in future specialist skills development. International Journal of Management, 11(4), 645-656. https://doi.org/10.34218/IJM.11.4.2020.062

Smolyar, A. I., \& Chernomyrdina T. N. (2019). Examining future teachers' psychological readiness for working under the conditions of inclusive education. Research Result. Pedagogic and Psychology of Education, 5(3), 72-84. https://doi.org/10.18413/2313-8971-2019-5-3-0-6

State Service for Education Quality of Ukraine. (2021). Inclusive quality research training for children with special needs educational needs. December 2020 - January 2021. Retrieved from https://mon.gov.ua/storage/app/media/inkluzyvne-navchannya/2021/04/02/Doslidzhennya_yakosti_inklyuzyvno yi_osvity_1_02_04.pdf

Tarabanovskaya, E. A., Romanovskaya, I. A., \& Treshchov, A. M. (2020). The Influence of Inclusively-oriented courses on the level of formation of future teachers' inclusive competence in the process of training. In: I. Gafurov \& R. Valeeva, (Eds.), VI International Forum on Teacher Education (pp. 2483-2496). Kazan, Russian Federation: Kazan Federal University. https://doi.org/10.3897/ap.2.e2483

Tserklevych, V., Prokopenko, O., Goncharova, O., Horbenko, I., Fedorenko, O., \& Romanyuk, Y. (2021). Virtual Museum Space as the innovative tool for the student research practice. International Journal of Emerging Technologies in Learning, 16(14), 213-231. https://doi.org/10.3991/ijet.v16i14.22975

Van Rensburg, H., \& Adcock, B. (2020). The challenges of inclusive education in developing countries in South East Asia. In H. van Rensburg, \& S. O'Neill (Eds.), Inclusive theory and practice in special education (pp. 1-18). Hershey, PA: IGI Global. http://doi:10.4018/978-1-7998-2901-0.ch001

Yashchuk, O. M., Yashchuk, S. M., Kobernyk, H. I., Kotlovyi, S. A., \& Biletska, I. O. (2020). Examining the formation of integrative readiness of pre-service teachers to work in inclusive classrooms in Ukraine. International Journal of Higher Education, 9(5), 208-222. https://doi.org/10.5430/ijhe.v9n5p208

Zhuravlova, Y., Kichuk, N., Zhuravska, N., Yakovenko, O., Zhytnyk, V., \& Yashchuk, S. (2021). The problem field of professional (vocational) education: Innovations and ways to improve. Estudios de Economia Aplicada, 39(5). https://doi.org/10.25115/eea.v39i5.5274

\section{Copyrights}

Copyright for this article is retained by the author(s), with first publication rights granted to the journal.

This is an open-access article distributed under the terms and conditions of the Creative Commons Attribution license (http://creativecommons.org/licenses/by/4.0/). 